\title{
THE DERMATOPHYTE TRICHOPHYTON RUBRUM SECRETES AN EDTA-SENSITIVE ALKALINE PHOSPHATASE ON HIGH-PHOSPHATE MEDIUM
}

\author{
Monica S. Ferreira-Nozawa ${ }^{1,2}$; Sérgio R. Nozawa ${ }^{1}$; Nilce M. Martinez-Rossi ${ }^{1 *}$; Antonio Rossi ${ }^{3}$ \\ ${ }^{1}$ Departamento de Genética, Faculdade de Medicina de Ribeirão Preto, Universidade de São Paulo, Ribeirão Preto, SP, Brasil; \\ ${ }^{2}$ Instituto de Biociências, Universidade Estadual Paulista, Rio Claro, SP, Brasil; ${ }^{3}$ Departamento de Bioquímica e Imunologia, \\ Faculdade de Medicina de Ribeirão Preto, Universidade de São Paulo, Ribeirão Preto, SP, Brasil
}

Submitted: August 05, 2002; Returned to authors for corrections: April 10, 2003; Approved: May 08, 2003.

\begin{abstract}
In this communication, we show that the growth of isolate $\mathrm{H} 6$ of the dermatophyte Trichophyton rubrum on non-buffered medium and under saturating phosphate conditions is dependent on the initial growth $\mathrm{pH}$, with an apparent optimum at $\mathrm{pH}$ 4.0. In addition, irrespective of the initial growth $\mathrm{pH}$, the $\mathrm{pH}$ of the medium altered during cultivation reaching values that ranged from 8.3 to 8.9. Furthermore, this isolate synthesized and secreted almost the same levels of an alkaline phosphatase with an apparent optimum $\mathrm{pH}$ ranging from 9.0 to 10.0 when grown on both low- and high-phosphate medium. Also, this alkaline phosphatase is activated by $\mathrm{Mg}^{2+}$ and is EDTA-sensitive. On the other hand, the very low levels of the enzyme retained by the mycelium grown on buffered medium at $\mathrm{pH}$ 5.0-5.2 suggest that this enzyme is encoded by an alkaline gene, i.e., a gene responsive to ambient $\mathrm{pH}$ signaling.
\end{abstract}

Key words: alkaline phosphatase, ambient $\mathrm{pH}$, dermatophytes, enzyme secretion, Trichophyton rubrum, Pi sensing

\section{INTRODUCTION}

Trichophyton rubrum, a filamentous fungus which causes infections in human skin and nails, is recognized as cosmopolitan and is one of the most frequently encountered dermatophytes $(1,4)$. However, this fungus which normally causes wellcharacterized superficial infections has been recently described as an invasive pathogen in immunocompromised hosts (12).

Although several factors contribute to the pathogenicity of dermatophytes, the successful initiation of infection is a process closely related to the capacity of the infecting fungus to overcome the host resistance mechanisms, which include the fungistatic fatty acids and the intact keratinized layers of the skin, and other physiochemical effectors such as moisture and skin $\mathrm{pH}$ (21). The capacity of dermatophytes to adhere to cell surfaces has been attributed to the presence of glycoproteins containing mannans in the cell wall of these microorganisms, and the greater their adherence capacity, the greater their invasive ability and virulence (26). However, for dermatophytes to be successful in their installation in the host the arthroconidia must germinate very rapidly and the hyphae penetrate the body surface or they will be lost by continuous desquamation of the epithelium.

Once established, the dermatophytes must scavenge nutrients for growth, an adaptive response to the environment relatively well known in model fungi such as Neurospora crassa and Aspergillus nidulans. For example, the use of nucleic acids as sources of inorganic phosphate (Pi) is based on the induction of structural proteins, permeases, and enzymes of the cell wall, in addition to the secretion of a variety of proteins and hydrolytic enzymes such as nucleases and acid and alkaline phosphatases in response to both $\mathrm{Pi}$ starvation and environmental $\mathrm{pH}$ signaling. This metabolic machinery permits the fungi, and other microorganisms, to use these macromolecules as sources of essential nutrients within a broad ambient $\mathrm{pH}$ range $(8,11,17,19)$. Thus, it is also important to understand the metabolic responses that govern homeostatic $\mathrm{pH}$ and extracellular $\mathrm{pH}$ sensing in dermatophytes, since the pathogenicity of many microorganisms has been demonstrated to depend on the sensing of ambient

* Corresponding author. Mailling address: Departamento de Genética, FMRP, Av. Bandeirantes 3900. 14049-900, Ribeirão Preto, SP, Brasil. Telephone: (+5516) 6023150. Fax: (+5516) 6330069. E-mail: nmmrossi@fmrp.usp.br 
$\mathrm{pH}$ in the host and on the ability to adapt, which involves installation, development, and survival in the host.

In order to investigate further the response of dermatophytes to ambient $\mathrm{pH}$, our first aim was to measure the derepression and secretion of alkaline phosphatases (APases) synthesized by isolate $\mathrm{H} 6$ of the dermatophyte T. rubrum on the basis of enzymatic activity. We observed the secretion of apparently only one APase irrespective of the extracellular Pi levels, which is possibly encoded by an alkaline gene, i.e., a gene responsive to ambient $\mathrm{pH}$ signaling.

\section{MATERIALS AND METHODS}

The clinical T. rubrum isolate (H6) obtained from a patient admitted to the University Hospital of the Faculty of Medicine of Ribeirão Preto, SP, Brazil, and identified by standard methods (16) was stored at room temperature in Sabouraud glucose agar medium (3) covered with sterilized water until the time of use.

After incubation of isolate $\mathrm{H} 6$ on Sabouraud glucose agar for 12 days at $28^{\circ} \mathrm{C}$, conidia and mycelium from three Petri dishes (14 $\mathrm{cm}$ diameter) were carefully harvested in $300 \mathrm{~mL}$ Sabouraud glucose liquid medium and cultured in an orbital shaker $(160 \mathrm{rpm})$ at $28^{\circ} \mathrm{C}$. After shaking for $96 \mathrm{~h}$ the culture was centrifuged $(15 \mathrm{~min}$ at $11,000 \mathrm{x} \mathrm{g}$ at $4^{\circ} \mathrm{C}$ ), the pellet resuspended in $50 \mathrm{~mL} 0.9 \%(\mathrm{w} / \mathrm{v})$ $\mathrm{NaCl}$ and centrifuged again for $10 \mathrm{~min}$ at $11,000 \mathrm{xg}$ at $4^{\circ} \mathrm{C}$. This procedure was repeated twice and the pellet free of Sabouraud medium was suspended in $50 \mathrm{mM} 0.9 \%(\mathrm{w} / \mathrm{v}) \mathrm{NaCl}$. Twenty $\mathrm{mL}$ of this suspension was inoculated into $100 \mathrm{mM}$ of low- $(200 \mu \mathrm{M}$ $\left.\mathrm{KH}_{2} \mathrm{PO}_{4}\right)$ and high-Pi $(10 \mathrm{mM})$ minimal liquid medium of Cove (9). Low-Pi medium was prepared by adding $200 \mu \mathrm{M} \mathrm{KH}_{2} \mathrm{PO}_{4}$ and 10 $\mathrm{mM} \mathrm{KCl}$ to Pi-free minimal medium (final concentrations). Both high- and low-Pi media were supplemented (final concentrations) with $50 \mathrm{mM}$ glycine, $1 \%$ (v/v) glycerol, and $70 \mathrm{mM} \mathrm{NaNO}_{3}$, and the $\mathrm{pH}$ was adjusted as desired. After incubation for $72 \mathrm{~h}$ in an orbital shaker $(160 \mathrm{rpm})$ at $28^{\circ} \mathrm{C}$, the mycelium was harvested by filtration, washed with distilled water and pressed to remove excess liquid. It was then ground in a pre-cooled mortar with washed sand and $20 \mathrm{mM}$ Tris $\mathrm{HCl}$ buffer, $\mathrm{pH} 8.9[10 \mathrm{~mL}$ buffer ( $\mathrm{g}$ mycelium $)^{-1}$, containing $1 \mathrm{mM} \mathrm{PMSF}$ and $1 \mathrm{mM}$ benzamidine, $4^{\circ} \mathrm{C}$. The mycelial extract was centrifuged at $20,000 \mathrm{xg}$ for $20 \mathrm{~min}$, and the supernatant used for enzyme assays without further treatment (mycelial extract). An appropriate volume of the harvested culture medium was concentrated about 40 times by ultrafiltration through AMICON (YM10) membranes and used for enzyme assays without further treatment (culture medium).

The enzymatic activity was determined in $0.3 \mathrm{M}$ Tris $\mathrm{HCl}$, $\mathrm{pH} 8.9$, containing one $\mathrm{mM} \mathrm{MgSO}_{4}$, using six $\mathrm{mM} \rho$-nitrophenyl phosphate (PNP-P) as substrate at $37^{\circ} \mathrm{C}$, a cocktail used to assay the constitutive APase from N. crassa (14). One Unit of enzyme activity was defined a one $\eta$ mol substrate hydrolyzed $\mathrm{min}^{-1}$. Specific activities were expressed as Units (mg dry weight mycelium $)^{-1}$. The S.D. was calculated from two replicates. At least two independent experiments were carried out. The buffers used to cover the $\mathrm{pH}$ range required were $0.1 \mathrm{M}$ MOPS, $\mathrm{pH} 7.0-$ 7.5, 0.1 M Tris HCl, $\mathrm{pH}$ 7.5-8.5, 0.1 M TAPS, $\mathrm{pH}$ 8.5-9.5, and 0.1 MCAPS, pH 9.5-10.5. APase activity was determined using the standard procedure.

\section{RESULTS}

Growth of isolate $\mathrm{H} 6$ of T. rubrum on a mixture of glycine and glycerol under saturating Pi conditions is dependent on the initial growth $\mathrm{pH}$, with an apparent optimum at $\mathrm{pH}$ 4.0. In addition, irrespective of the growth $\mathrm{pH}$, the $\mathrm{pH}$ of the medium altered during cultivation, reaching values that ranged from 8.3 to 8.9 (Table 1 ).

Table 2 shows that isolate $\mathrm{H} 6$ of T. rubrum synthesized and secreted almost the same levels of an APase when grown on both low- and high-Pi medium, as measured by the enzymatic

Table 1. Growth of isolate H6 of Trichophyton rubrum in nonbuffered high-phosphate minimal liquid medium. The dermatophyte was cultured for 4 days in an orbital shaker (160 $\mathrm{rpm})$ at $28^{\circ} \mathrm{C}$. For details see Materials and Methods.

\begin{tabular}{ccc}
\hline Initial $\mathrm{pH}$ & Final $\mathrm{pH}$ & $\begin{array}{c}\text { mycelial dry weight } \\
(\mathrm{g} / 100 \mathrm{~mL} \text { medium })\end{array}$ \\
\hline 3.0 & 8.3 & $1.8 \pm 0.3$ \\
4.0 & 8.4 & $2.0 \pm 0.3$ \\
6.8 & 8.5 & $1.4 \pm 0.2$ \\
8.0 & 8.6 & $0.5 \pm 0.1$ \\
9.0 & 8.9 & $0.2 \pm 0.1$ \\
\hline
\end{tabular}

Table 2. Effect of culture conditions on the production and secretion of alkaline phosphatase in Trichophyton rubrum $^{(a)}$.

\begin{tabular}{|c|c|c|c|c|c|}
\hline \multirow{2}{*}{$\begin{array}{l}\text { Culture } \\
\text { conditions }\end{array}$} & \multirow{2}{*}{$\begin{array}{c}\text { mycelial } \\
\text { dry weight } \\
\text { (g/100mL) }\end{array}$} & \multirow{2}{*}{$\begin{array}{c}\text { Initial } \\
\mathrm{pH}\end{array}$} & \multirow{2}{*}{$\begin{array}{c}\text { Final } \\
\mathrm{pH}\end{array}$} & \multicolumn{2}{|c|}{$\begin{array}{c}\text { Alkaline } \\
\text { Phosphatase }^{(\mathrm{b})}\end{array}$} \\
\hline & & & & $\begin{array}{c}\text { Mycelial } \\
\text { extract }\end{array}$ & \\
\hline High-Pi ( & & 6.8 & 8.5 & & $72 \pm 1$ \\
\hline & $0.8 \pm$ & 6.8 & 8.6 & $84 \pm 3$ & $93 \pm 2$ \\
\hline \multirow{3}{*}{ High-Pi $(10 \mathrm{mM})^{(\mathrm{d})}$} & & 5.0 & 5.2 & & \\
\hline & $0.6 \pm$ & 6.8 & 7.0 & & $14 \pm 1$ \\
\hline & $0.8 \pm 0.2$ & 8.0 & 7.9 & $47 \pm 3$ & $13 \pm 1$ \\
\hline
\end{tabular}

(a) Isolate $\mathrm{H} 6$ of the dermatophyte was grown in Sabouraud dextrose liquid medium under saturating phosphate conditions, transferred to low- and high-Pi minimal liquid medium, and then incubated for 3 days in an orbital shaker $(160 \mathrm{rpm})$ at $28^{\circ} \mathrm{C}$; (b) Enzyme activity over PNP-P. Units (mg dry weight mycelium) ${ }^{-1}$; ${ }^{(c)}$ Non-buffered medium; ${ }^{(d)}$ Buffered medium with $50 \mathrm{mM} \mathrm{Na}$ citrate ( $\mathrm{pH}$ 5.0), $50 \mathrm{mM}$ PIPES (pH 6.8), and $50 \mathrm{mM}$ Tris-HCl (pH 8.0); For details see Materials and Methods. 
hydrolysis of PNP-P. When the dermatophyte was grown on buffered medium the production and secretion of the enzyme was repressed at $\mathrm{pH} 5.0$, and reduced at both $\mathrm{pH} 6.8$ and 8.0 (Table 2). As previously observed for APases synthesized by other fungi, the $\mathrm{pH}$ activity profile showed an apparent optimum $\mathrm{pH}$ ranging from 9.0 to 10.0 for both mycelial and secreted enzymes, irrespective of the extracellular Pi levels (Fig. 1). Also, this APase is activated by $\mathrm{Mg}^{2+}$ and is EDTA-sensitive (Fig. 2).

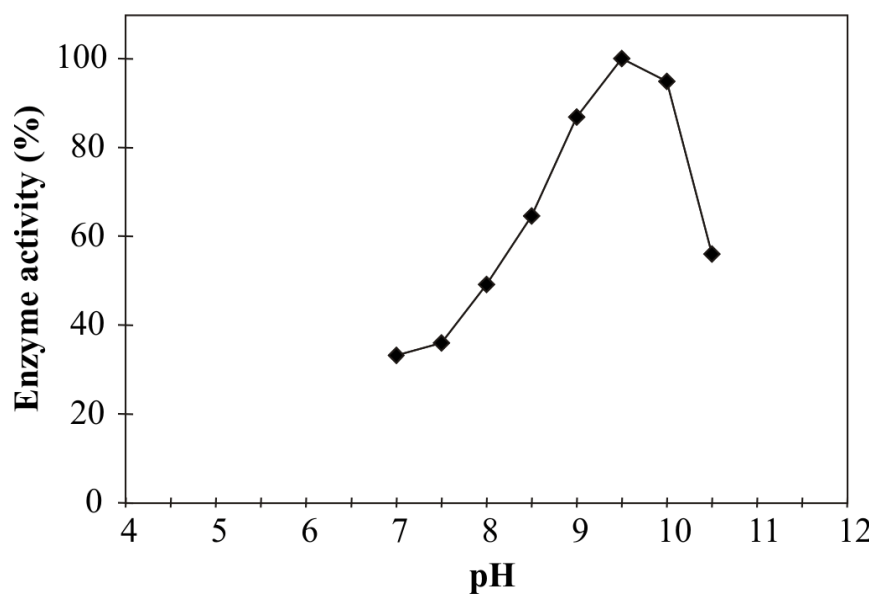

Figure 1. $\mathrm{pH}$ activity profile of alkaline phosphatase secreted by isolate $\mathrm{H6}$ of Trichophyton rubrum grown in non-buffered high-phosphate medium at $28^{\circ} \mathrm{C}, \mathrm{pH}$ 6.8. For details see Material and Methods.

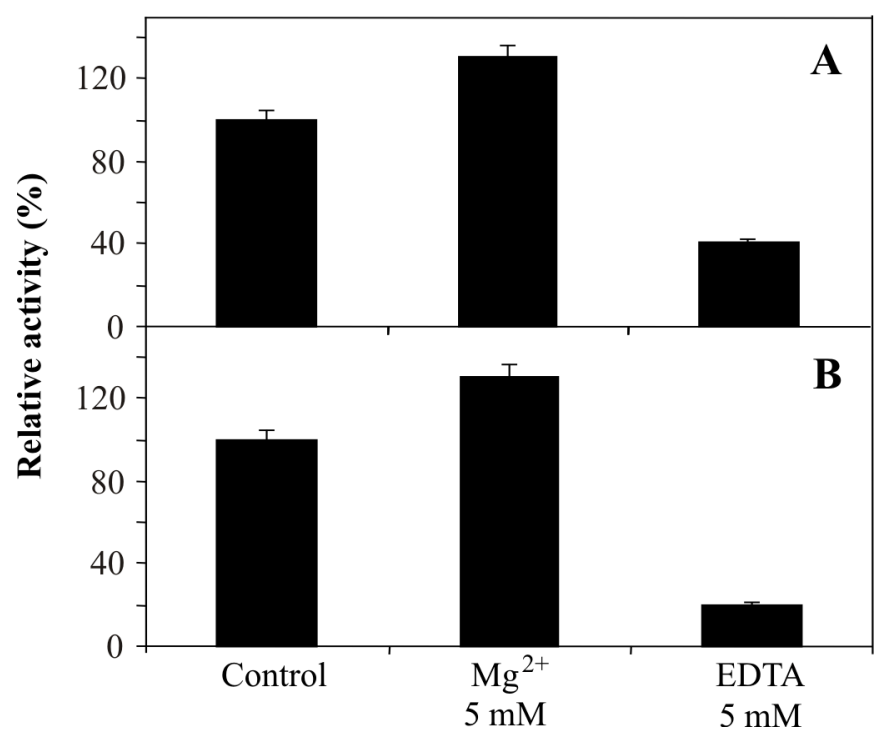

Figure 2. Effect of $\mathrm{Mg}^{2+}$ and EDTA on the $p$ nitrophenylphosphatase activity, $\mathrm{pH} 8.9$, of alkaline phosphatase synthesized by isolate H6 of Trichophyton rubrum grown in high-phosphate medium at $28^{\circ} \mathrm{C}, \mathrm{pH} 6.8$. (A) mycelium extract; (B) culture medium. For details see Materials and Methods.

\section{DISCUSSION}

The fungi, and probably all living organisms, synthesize a number of phosphatases which are necessary to scavenge $\mathrm{Pi}$ from medium containing nucleic acids as the sole phosphorus source, i.e., these enzymes are secreted in response to signals of the absence of $\mathrm{Pi}$ (22). The regulation of this adaptive response has proved to be highly complex, not only because of the identification of a large number of genes involved in the signaling of Pi starvation, but also because the synthesis and secretion of these enzymes are under the action of nitrogen, carbon and $\mathrm{pH}$ regulatory circuits $(8,13,19)$. The $\mathrm{pH}$ regulatory mechanism ensures that extracellular enzymes are secreted only at $\mathrm{pH}$ values at which they can function effectively. For example, acid and alkaline Pirepressible phosphatases are secreted into the growth medium at acid and alkaline $\mathrm{pH}$, respectively $(14,19)$. However, there is increasing evidence indicating that $N$. crassa secretes similar amounts of the pho-2-encoded Pi-repressible APase irrespective of ambient $\mathrm{pH}$ when wild-type strains grow in low-Pi medium, i.e., gene $p h o-2$, which is responsive to Pi starvation via a hierarchical regulatory circuit (20), is not an alkaline gene. Interestingly, the synthesis and secretion of an APase is apparently nonresponsive to Pi starvation in the dermatophyte T. rubrum, since the synthesis and secretion of the APase occurs constitutively (Table 2). In addition, its sensitivity to EDTA (Fig. 2) and dependence on $\mathrm{Mg}^{2+}$ ions are properties related to the constitutive APase synthesized, but not secreted, by $N$. crassa (18). The pho-2-encoded Pi-repressible APase secreted by $N$. crassa is activated by EDTA, and therefore is not dependent on cations for its catalytic activity (24).

In conclusion, the above results suggest that the secretion of an APase by T. rubrum not only relies on independent Pi signaling mechanisms (11), but is also apparently the only APase secreted by this dermatophyte. On the other hand, the very low levels of this phosphatase retained by the mycelium grown on buffered medium at pH 5.0-5.2 (Table 2) lead us to believe that this enzyme is encoded by an alkaline gene. Dermatophytes grow logarithmically in the initial stages of infection, derepressing nonspecific proteolytic enzymes, among others, with optimum activity at acid $\mathrm{pH}$ whenever a carbon, nitrogen or sulfur source is lacking in the environment, probably because human skin has a weakly acidic $\mathrm{pH}$ (10). It is noteworthy that proteinases with an optimal activity under acidic conditions are important virulence factors in the dermatophytes (25). These proteases act on keratinous and non-keratinous substrates in the stratum corneum, releasing peptides that are hydrolyzed to amino acids by putative peptidases. According to Apodaca and McKerrow (2), the amino acids released in this process may repress the synthesis of nonspecific proteases and may induce the synthesis of keratinases. However, the utilization of some amino acids by fungi that generate cytoplasmic acetyl $\mathrm{CoA}$, such as glycine, for example (Table 1), promotes alkalinization of the growth medium raising 
the $\mathrm{pH}$ up to values as high as 9.0 (23), an ambient in which most of the known keratinolytic proteases have optimal enzymatic activity (7). Alkalinization predominates over glucose or related sugar-induced acidification of the extracellular medium when the fungi grow on a mixture of glucose and carbon sources generating cytoplasmic acetyl CoA such as acetate or glycine $(15,23)$. Thus, it is possible that the secretion of this APase that is not responsive to Pi starvation is necessary for the dermatophyte to complete its installation, to develop, and to remain in the host $(5,6)$.

\section{ACKNOWLEDGEMENTS}

This research was supported by FAPESP, CNPq, CAPES and FAEPA (FMRP-USP). M.S.F-N and S.R.N were supported by student fellowships from FAPESP. We thank Mrs Elettra Greene for revising the manuscript.

\section{RESUMO}

\section{O dermatófito Trichophyton rubrum secreta uma fosfatase alcalina EDTA-sensível em meio contendo alta concentração de fosfato}

Nesta comunicação nós mostramos que o crescimento do isolado H6 do dermatófito T. rubrum em meio não tamponado e sob condição saturante de fosfato, é dependente do $\mathrm{pH}$ inicial de cultivo, com um ótimo aparente em $\mathrm{pH} 4,0$. Além disto, independente do $\mathrm{pH}$ inicial, o $\mathrm{pH}$ do meio se altera durante o cultivo alcançando valores que variam de 8,3 a 8,9. Verificou-se também que este isolado sintetiza e secreta quase os mesmos níveis de fosfatase alcalina, com um ótimo de atividade aparente entre os valores de pH 9,0 e 10,0, independentemente da concentração de fosfato no meio. Também mostramos que essa fosfatase alcalina é inibida por EDTA e ativada por $\mathrm{Mg}^{2+}$. Por outro lado, o nível dessa enzima retida no micélio cultivado em meio tamponado em $\mathrm{pH}$ 5,0-5,2 é baixo, sugerindo que ela seja codificada por um gene alcalino, isto é, um gene responsivo à sinalização pelo $\mathrm{pH}$ ambiente.

Palavras-chave: dermatófitos, fosfatase alcalina, $\mathrm{pH}$ ambiente, regulação fosfato, secreção enzimática, Trichophyton rubrum

\section{REFERENCES}

1. Anstey, A.; Lucke, T.W.; Philpot, C. Tinea capitis caused by Trichophyton rubrum. Br. J. Dermatol., 135: 113-115, 1996.

2. Apodaca, G.; McKerrow, J.H. Regulation of Trichophyton rubrum proteolytic activity. Infect. Immun., 57: 3081-3090, 1989.

3. Atlas, R.M. Handbook of Microbiological Media, Parks LC, CRC Press, 1993, 1079p.

4. Bièvre, C.; Dujon, B. Organization of the mitochondrial genome of Trichophyton rubrum. DNA sequence analysis of the ND4 gene, the ATPase subunit-6 gene, the ribosomal RNA small-subunit gene, the ND6 gene, the COXIII gene, the ATPase subunit- 8 gene and six tRNA genes that correspond respectively to the tyrosine, lysine, glutamine, asparagine, isoleucine and tryptophan isoacceptors. Curr. Genet., 28: 553-559, 1995.

5. Brasch, J.; Zaldua, M. Enzyme patterns of dermatophytes. Mycoses, 37: 11-16, 1994.

6. Brasch, J.; Martins, B.S.; Christophers, E. Enzyme release by Trichophyton rubrum depends on nutritional conditions. Mycoses, 9/10: 365-368, 1991.

7. Brouta, F.; Descamps, F.; Fett, T.; Losson, B.; Gerday, C.; Mignon, B. Purification and characterization of a $43.5 \mathrm{kDa}$ keratinolytic metalloprotease from Microsporum canis. Med. Mycol., 39: 269$275,2001$.

8. Caddick, M.X.; Brounlee, A.G.; Arst, H.N. Jr. Regulation of gene expression by $\mathrm{pH}$ of the growth medium in Aspergillus nidulans. Mol. Gen. Genet., 203: 346-353, 1986.

9. Cove, D.J. The induction and repression of nitrate reductase in the fungus Aspergillus nidulans. Biochim. Biophys. Acta, 113: 51-56, 1966.

10. Cutler, J.E. Putative virulence factors of Candida albicans. Annu. Rev. Microbiol., 45: 187-218, 1991.

11. Davis, R.H. Neurospora Contributions of a Model Organism. Oxford University Press, New York, 2000, 333p.

12. Grossman, M.E.; Pappert, A.S.; Garzon, M.C.; Silvers, D.N. Invasive Trichophyton rubrum infection in the immunocompromised host: report of three cases. J. Am. Acad. Dermatol., 33: 315-318, 1995.

13. Grove, G.; Marsluf, G.A. Nitrogen regulation of acid phosphatase in Neurospora crassa. J. Bacteriol., 141: 1470-1473, 1980.

14. Han, S.W.; Nahas, E.; Rossi, A. Regulation of synthesis and secretion of acid and alkaline phosphatases in Neurospora crassa. Curr. Genet., 11: 521-527, 1987.

15. Maccheroni, W. Jr.; Pombeiro, S.R.C.; Martinez-Rossi, N.M.; Rossi, A. $\mathrm{pH}$ and acid phosphatase determinations after growth of Aspergillus nidulans on solid medium. Fungal Genet. Newsl., 38: 78-79, 1992.

16. McGinnis, M.R. Laboratory handbook of Medical Mycology. Academic Press, New York, 1980.

17. Meunier, J.R.; Grimont, P.A.D. Factors affecting reproducibility of random amplified polymorphic DNA fingerprinting. Res. Microbiol., 144: 373-379, 1993.

18. Morales, A.C.; Nozawa, S.R.; Thedei, G. Jr.; Maccheroni, W. Jr.; Rossi, A. Properties of a constitutive alkaline phosphatase from strain 74A of the mold Neurospora crassa. Brazilian J. Med. Biol. Res., 33: 905-912, 2000.

19. Nahas, E.; Terenzi, H.F.; Rossi, A. Effect of carbon source and pH on the production and secretion of acid phosphatase (EC 3.1.3.2) and alkaline phosphatase (EC 3.1.3.1) in Neurospora crassa. J. Gen. Microbiol., 128: 2017-2021, 1982.

20. Nozawa, S.R.; Thedei, G. Jr.; Crott, L.S.P.; Barbosa, J.E.; Rossi, A. The synthesis of phosphate-repressible alkaline phosphatase do not appear to be regulated by ambient $\mathrm{pH}$ in the filamentous mould Neurospora crassa. Brazilian J. Microbiol., 33: 92-95, 2002.

21. Ogawa, H.; Summerbell, R.C.; Clemons, K.V.; Koga, T.; Ran, Y.P.; Rachid, A.; Sohnle, P.G.; Stevens, D.A.; Tsuboi, R. Dermatophytes and host defense in cutaneous mycoses. Med. Mycol., 36: 166-173, 1998.

22. Peleg, Y.; Addison, R.; Aramayo, R.; Metzenberg, R.L. Translocation of Neurospora crassa transcription factor NUC-1 into the nucleus is induced by phosphorus limitation. Fungal Genet. Biol., 20: 185-191, 1996.

23. Thedei, G. Jr.; Doubowetz, T.H.; Rossi, A. Effect of carbon source and extracellular $\mathrm{pH}$ on the acidification of the culture medium and phosphatase excretion in Neurospora crassa. Brazilian J. Med. Biol. Res. 27: 1129-1134, 1994.

24. Thedei, G. Jr.; Nozawa, S.R.; Simões, A.L; Rossi, A. Gene pho-2 codes for the multiple active forms of Pi-repressible alkaline phosphatase in the mold Neurospora crassa. World J. Microbiol. Biotechnol., 13: 609-611, 1997.

25. Tsuboi, R.; Ko, I.K.; Takamori, K.; Ogawa, H. Isolation of keratinolytic proteinase from Trichophyton mentagrophytes with enzymatic activity at acidic pH. Infect. Immun., 57: 3479-3483, 1989.

26. Weitzman, I.; Summerbell, R.C. The dermatophytes. Clin. Microbiol. Rev., 8: 240-259, 1995. 